\title{
Correlation between the willingness to compromise and effectiveness of regional regulations with green consumer behaviour
}

\author{
LINA LINA, RITA RETNOWATI, YOSSA ISTIADI \\ Jl. Pakuan PO. Box 452, Bogor 16143, Indonesia \\ Corresponding author: linasimon06@gmail.com
}

Study Programme of Environmental Management, Graduate School, Pakuan University

Submitted 10 October 2021; Accepted 27 October 2021

\begin{abstract}
The objective of this study is to find the correlation between the effectiveness level of regional regulations and willingness to compromise with green consumer behaviour. This research applied use correlational surveys with 100 samples housewives in Bogor city. The data analysis technique used is multiple regression. The result of this research shows that there is a very significant positive relationship that has a local regulation permit with green consumer behaviour, with a variable contribution of $56.2 \%$. There is a very significant positive relationship between willingness to compromise with green consumer behaviour, with the variable contribution being $38.3 \%$. There is a very significant positive relationship between the application of local regulations and the willingness to compromise together with green consumer behaviour, with the variable contribution being $57.9 \%$. The functional relationship between the application of local regulations and willingness to compromise with the green consumer behaviour variable fulfills the regression equation $\hat{Y} 12=21.866+0.404 \mathrm{X} 1+0.214 \mathrm{X} 2$ and this relationship is significant.
\end{abstract}

\begin{abstract}
ABSTRAK
Tujuan dari penelitian ini adalah untuk mengetahui hubungan antara tingkat efektivitas peraturan daerah dan kemauan berkompromi dengan perilaku konsumen hijau. Penelitian ini menggunakan metode survei korelasional dengan sampel 100 ibu rumah tangga di kota Bogor. Teknik analisis data yang digunakan adalah regresi berganda. Hasil penelitian menunjukkan bahwa terdapat hubungan positif yang sangat signifikan antara izin peraturan daerah dengan perilaku konsumen hijau, dengan kontribusi variabel sebesar $56,2 \%$. Terdapat hubungan positif yang sangat signifikan antara kesediaan berkompromi dengan perilaku konsumen hijau, dengan kontribusi variabel sebesar 38,3\%. Terdapat hubungan positif yang sangat signifikan antara penerapan peraturan daerah dengan kemauan berkompromi dengan perilaku konsumen hijau, dengan kontribusi variabel sebesar $57,9 \%$. Hubungan fungsional antara penerapan peraturan daerah dan kemauan berkompromi dengan variabel perilaku konsumen hijau memenuhi persamaan regresi $\hat{Y} 12=21,866+0,404 \mathrm{X} 1+0,214 \mathrm{X} 2$ dan hubungan ini signifikan.
\end{abstract}

Keywords: effectiveness, green consumer behaviour, local regulations, willingness to compromise

\section{INTRODUGTION}

Fast economic growth encouraging the happening of consumption and natural resources exploitation in excessive way so that it inflicts environmental damage. The implication of environmental damage according to (Biswas \& Roy, 2014) include global warming, environmental degradation (soil, air, and water), depletion of ozone layer, and as well as having an impact on the decline in the quality of social life and health caused by.

From all the types of trash, the most dangerous is certainly plastic waste. These days, the society using plastic as the food container and as well as other functions. Disposable food containers that made of plastic are considered more practical, whereas like what we know that this plastic material is difficult to decompose by soil. To this day, Indonesian Government continues to strive to reduce the amount of plastic waste. The various policies and program are arranged as the step in the reduction of plastic waste. Program trial have conducted in 2016 to reduce plastic waste by charging a fee of two hundred rupiah for the consumers who want to use plastic bag for their groceries. At that time, the government collaborated with retailers and supermarkets to support the trial of that policy.

In compiling the laws and regulations, the local government loads and manages the application of regional autonomy and accommodates the particular conditions of the region. The local government has the authority and as well as the independence in managing all regional government affairs, in order to run their respective regional autonomy.

This research is a continuation of the previous relevant research about how effective the local regulations on public awareness of environmental care practice, and would like to find correlation between the effectiveness of regional regulations application and green consumer behaviour, correlation between willingness to compromise and green consumer behaviour, as well as correlation between regional regulations and willingness to compromise simultaneously with the green consumer behaviour. 


\section{METHODS}

The research design that is used in this research is quantitative correlational survey design as seen on below diagram (Figure 1).

The population of housewives with the sample in this research was using random sampling or gradually sample (stratified sampling). The sampling process carried out in stages. According to Slovin formula, so that the sample that should be examined is minimum of 100 samples.

The data collecting technique was carried out using a Likert scale instrument for the three variables. The data analysis technique used in this research was correlational analysis used to find the relation or the influence between one variable and another.

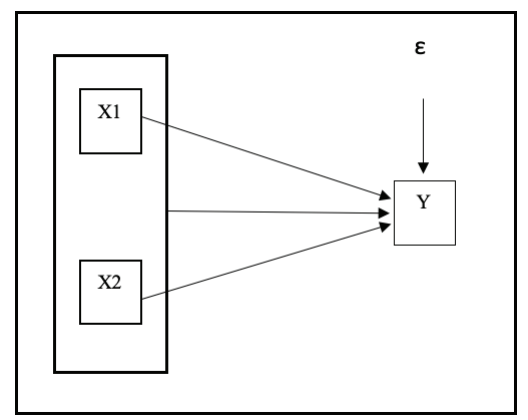

Figure 1. Diagram of research design

Where X1: the effectiveness of regional regulations application, X2 : willingness to compromise, Y: green consumer behaviour, and $\varepsilon$ : the other variables that are not examined

\section{RESULTS AND DISGUSSION}

\section{Correlation between the effectiveness of regional regulations application and green consumer behaviour}

Based on the research result, there is found very significant correlation between the effectiveness of regional regulations application with green consumer behaviour. The equation of regression is $\hat{\mathrm{Y}}=38.1786+$ $0.4876 \mathrm{X}_{1}$. (Figure 2). While there was coefficient of correlation 0.75 with significant different $\mathrm{t}$ test $(\mathrm{t}=11.217$; $\mathrm{p}<0.01)$.

Through ANOVA test could explain that very significant different $\mathrm{F}=5.827(\mathrm{p}<0.01)$ as is shown in Table 1.

The value of the coefficient of determination between effectiveness of regional regulations application variable and green consumer behaviour is $0.562(56.2 \%)$. This matter indicates that $56.2 \%$ of green consumer behaviour caused by the presence of effectiveness of regional regulations application, while $43.8 \%$ caused by the other factors. The functional relation namely regression between effectiveness regional regulations application $\left(\mathrm{X}_{1}\right)$ and green consumer behaviour $(\mathrm{Y})$ is as well as significant and that regression follows.

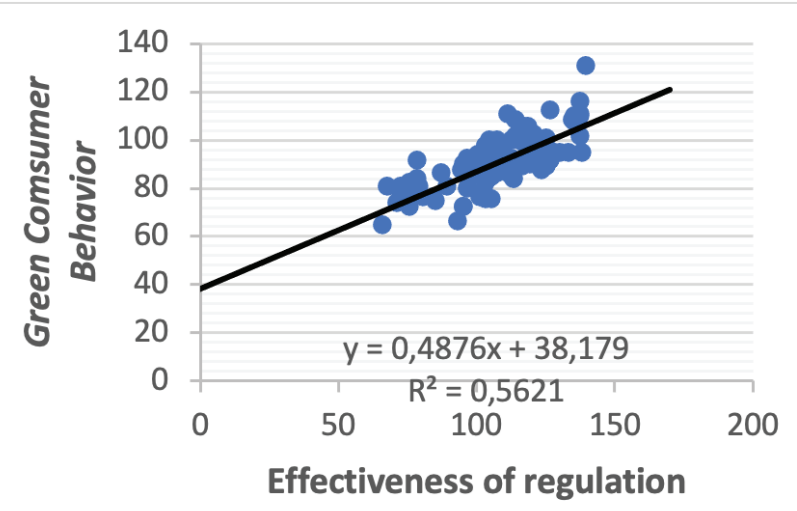

Figure 2. Regression equation of correlation between effectiveness of regulation with customers behaviour

\section{Correlation between willingness to compromise and green consumer behaviour}

Based on the research result, significant correlation was found between willingness to compromise variable and green consumer behaviour. The equation of regression $\hat{\mathrm{Y}}=5.4751+0.7199 \mathrm{X}_{2}$ (Figure 3). While there was coefficient of correlation 0,6189 with significant different $t$ test $(t=7.801 ; \mathrm{p}<0.01)$.

Through ANOVA test could explain that very significant different $\mathrm{F}=5.827(\mathrm{p}<0.01)$ as shown in Table 2.

The value of the coefficient of determination between willingness to compromise variable and green consumer behaviour is $0.383(38.3 \%)$. This matter indicates that $38.3 \%$ green consumer behaviour caused by the presence of willingness to compromise contribution, while $61.7 \%$ caused by the other factors. The functional relation namely regression between willingness to compromise $\left(\mathrm{X}_{2}\right)$ and green consumer behaviour $(\mathrm{Y})$ is as well as significant and the regression follows the equation $\hat{\mathrm{Y}}=5.4751+0.7199 \mathrm{X}_{2}$.

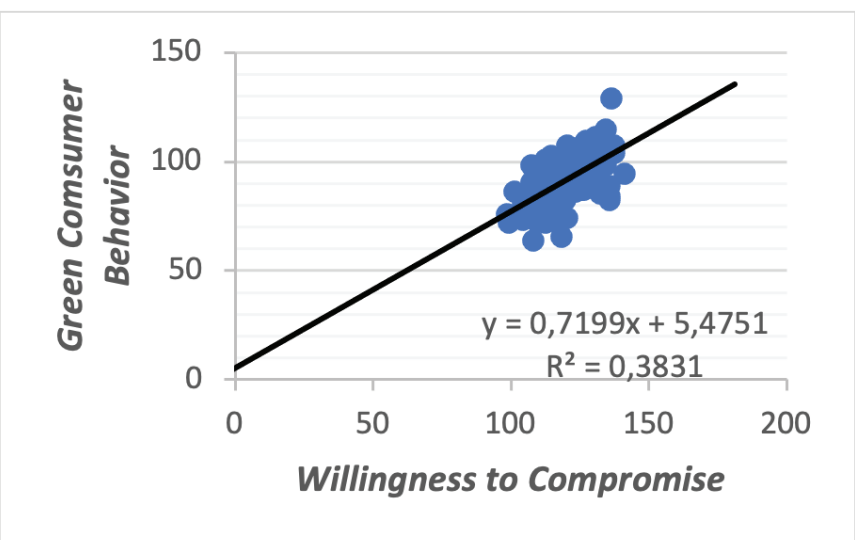

Figure 3. Regression equation between willingness to compromise with customers behaviour 


\section{Correlation between effectiveness of regional regulations application and willingness to compromises together with green consumer behaviour}

The correlation between effectiveness of regional regulations and willingness to compromise simultaneously have the correlation coefficient 0.761 thee as significant different, so that the determination coefficient is 0.579 and it indicates that $57.9 \%$ green consumer behaviour could be materialized from the presence of effectiveness of regional regulations application variable and willingness to compromise simultaneously and $42.1 \%$ is the contribution from the other factors. Functional relation, regression simultaneously between the effectiveness of Regional regulations and willingness to compromise with green consumer behaviour $(\mathrm{F}=66.7947 \mathrm{p}<0.01$; Table 3 ) also significant and the regression follows the equation $\hat{\mathrm{Y}}=$ $21.866+0.404 \mathrm{X}_{1}+0.214 \mathrm{X}_{2}$.

Both factors of effectiveness of regional regulations application and willingness to compromise simultaneously turned out to give contribution that significant for the enhancement of green consumer behaviour.

Table 1. ANOVA test of correlation between effectiveness of regulation with customers behaviour

\begin{tabular}{|c|c|c|c|c|c|c|c|}
\hline \multirow{2}{*}{ Source } & \multirow{2}{*}{ dk } & \multirow{2}{*}{ JK } & \multirow{2}{*}{ RJK } & \multirow{2}{*}{$\mathbf{F}$} & \multicolumn{2}{|c|}{ F table } & \multirow{2}{*}{ - Remarks } \\
\hline & & & & & 0.05 & 0.01 & \\
\hline Total & 100 & 839984.00 & & & & & \\
\hline Coefficient (a) & 1 & 826281.00 & 826281.00 & & & & \\
\hline Regression (b/a) & 1 & 769.03 & 769.03 & & & & \\
\hline \multirow[t]{2}{*}{ Residual (S) } & 98 & 12933.97 & 131.98 & $5.827 * *$ & 3.938 & 6.901 & Very Sig. \\
\hline & 49 & 144763.18 & 2954.35 & $0.918 \mathrm{~ns}$ & 1.607 & 1.962 & \\
\hline Error & 49 & 157697.15 & 3218.31 & & & & \\
\hline
\end{tabular}

Table 2. ANOVA test correlation between effectiveness of regulation with customers behaviour

\begin{tabular}{|c|c|c|c|c|c|c|c|}
\hline \multirow{2}{*}{ Source } & \multirow{2}{*}{$\mathbf{d k}$} & \multirow{2}{*}{ JK } & \multirow{2}{*}{ RJK } & \multirow{2}{*}{$\mathbf{F}$} & \multicolumn{2}{|c|}{ F table } & \multirow{2}{*}{ - Remarks } \\
\hline & & & & & 0.05 & 0.01 & \\
\hline Total & 100 & 839984.00 & & & & & \\
\hline Coefficient (a) & 1 & 826281.00 & 826281.00 & & & & \\
\hline Regression (b/a) & 1 & 1244.38 & 1244.38 & & & & \\
\hline \multirow[t]{2}{*}{ Residual (S) } & 98 & 12458.62 & 127.13 & $9.788 * *$ & 3.938 & 6.901 & Very Sig. \\
\hline & 36 & 145238.53 & 4034.40 & $1.586 \mathrm{~ns}$ & 1.607 & 1.956 & Linear \\
\hline Error & 62 & 157697.15 & 2543.50 & & & & \\
\hline
\end{tabular}

Table 3. Result of ANOVA regression of effectiveness of regional regulation application, willingness to compromise, and green consumer behaviour

\begin{tabular}{|c|c|c|c|c|c|c|c|}
\hline \multirow{2}{*}{ Source } & \multirow{2}{*}{$\mathbf{J K}$} & \multirow{2}{*}{ dh } & \multirow{2}{*}{ RJK } & \multirow{2}{*}{$\mathbf{F}$} & \multicolumn{2}{|c|}{ F table } & \multirow{2}{*}{ Remark } \\
\hline & & & & & $a=0.05$ & $a=0.01$ & \\
\hline Regression (b/a) & 7939 & 2 & 3969 & 66.7947 ** & 3.090 & 4.831 & Very Sig. \\
\hline Residual (S) & 5764 & 97 & 59.4259 & & & & \\
\hline Total & 13703 & 99 & & & & & \\
\hline
\end{tabular}

\section{CONGLUSION}

There is positive relation that highly significant between effectiveness of regional regulations application and green consumer behaviour. The function relation between effectiveness of regional regulations application and green consumer behaviour fulfill the regression equation $\hat{\mathrm{Y}}_{1}=38.1786+0.4876 \mathrm{X}_{1}$.

There is positive relation that highly significant between willingness to compromise and green consumer behaviour. The functional relation between willingness to compromise and green consumer behaviour fulfills the regression equation $\hat{\mathrm{Y}}_{2}=5.4751+0.7199 \mathrm{X}_{2}$ and that relation is significant.

There is positive relation that highly significant between effectiveness of regional regulations application and willingness to compromise simultaneously with green consumer behaviour fulfills the regression equation $\hat{\mathrm{Y}}_{12}=21.866+0.404 \mathrm{X}_{1}+$ $0.214 \mathrm{X}_{2}$.

\section{REFERENGE}

Biswas, A. \& Roy, M. (2014). Green products: An exploratory study on the consumer behaviour in emerging economies of the east. Fournal of Cleaner Production 87(1):463-468. https://doi.org/10.1016/j.jclepro.2014.09.075

Bonini, S. \& Oppenheim, J. (2008). Culvating the green consumer. Stanford Social Innovation Review 14(2):215-221. https://doi.org/10.1007/s12541-013-0030-1 
BPS. (2019). Kecamatan Bogor Timur Dalam Angka.

Budo, A., Tulusan, F. \& Tampi, G.B. (2019). Efektivitas pelayanan kesehatan di Rumah Sakit Pancaran Kasih Manado. Furnal Administrasi Publik 6(94):1-13.

Cruz, M.U.M. \& Prabawani, B. (2019). Konsumen ramah lingkungan: Perilaku konsumsi hijau Civitas Academia Universitas Diponegoro. Jurnal Online UTA45 53(9):1689-1699.

Dropulić, B. \& Krupka, Z. (2020). Are consumers always greener on the other side of the fence? Factors that influence green purchase intentions: The context of Croatian and Swedish consumers. Market-Trziste 32(Special Issue): 99-113. https://doi.org/10.22598/mt/2020.32.spec-issue.99

Dunn, W.N. (2003). Pengantar Analisis Kebijakan Publik. Gadjah Mada University Press, Yogyakarta. pp. 1-687.

Firmansyah, A. (2017). Pengaruh green intellectual capital dan organizational identity dan dampaknya terhadap green competitive advantage. Substansi 1(1):183-219.

Hanggarjati, W. (2016). Efektivitas Model Pembelajaran Project Work untuk Peningkatan Hasil Belajar Mata Pelajaran Teknik Digital Siswa Kelas X Program Keahlian Teknik Elektronika Industri di SMKN 2 Bawang.

Hanisch, K.A., Hulin, G.L. \& Roznowski, M. (1998). The importance of individuals' repertoires of behaviors: The scientific appropriateness of studying multiple behaviors and general attitudes. Fournal of Organizational Behavior 19(5): 463.

Hill, R.J., Fishbein, M. \& Ajzen, I. (1977). Belief, attitude, intention and behavior: An introduction to theory and research. Contemporary Sociology 6(2): 244.

https://doi.org/10.2307/2065853

Jansson, J., Marell, A. \& Nordlund, A. (2010). Green consumer behavior: Determinants of curtailment and eco-innovation adoption. Fournal of Consumer Marketing 27(4):358-370.

https://doi.org/10.1108/07363761011052396

Jayanti, N.D., Kumadji, S. \& Yaningwati, F. (2013). Analisis faktor-faktor yang mempengaruhi green purchasing. Furnal Administrasi Bisnis 5:1-?.

Khoiriyah, S. \& Toro, M.J.S. (2018). Attitude toward green product, willingness to pay and intention to purchase. International Fournal of Business and Society 19:620-628.

Lakra, P., Bedi, P. \& Gupta, E. (2014). Consumer behaviour with reference to green consumption and sustainability. International Research Fournal of Management Science \& Technology $5(4): 3-11$.

Le Gall-Ely, M. (2009). Definition, measurement and determinants of the consumer's willingness to pay: A critical synthesis and avenues for further research. Recherche et Applications En Marketing (English Edition), 24(2):91-112. https://doi.org/10.1177/205157070902400205
Lehmann, D.R. \& Pan, Y. (1994). Context effects, new brand entry, and consideration sets. Fournal of Marketing Research 31(3): 364-?. https://doi.org/10.2307/3152223

Luzio, J.P.P. \& Lemke, F. (2013). Exploring green consumers' product demands and consumption processes: The case of Portuguese green consumers. European Business Review 25(3):281-300.

https://doi.org/10.1108/09555341311314825

Lyon, T.P. (2003). "Green" firms bearing gifts. Regulation 26(3):36-40.

Mingkid, G.J., Liando, D. \& Lengkong, J. (2017). Efektivitas penggunaan dana desa dalam peningkatan pembangunan. Jurnal Eksekutif 2(2):

Muaddab, H. (2015). Faktor yang berpengaruh terhadap perilaku konsumsi hijau pada siswa SMK Negeri Se-Kabupaten Jombang. Furnal Edusentris 2(2):126-?. https://doi.org/10.17509/edusentris.v2i2.166

Najdah \& Aziz, A. (2017). The determinant factors of green consumption behavior. South East Asia Fournal of Contemporary Business, Economics and Law 12(2):16-22.

Novianti, A.I., \& Kartika, L. (2017). Pengaruh green marketing kebijakan kantong plastik berbayar terhadap green behaviour masyarakat Kota Bogor. 2(1): 81-94.

Novita, R.A., Prasetyo, A.B. \& Suparno. (2017). Efektivitas pelaksanaan Undang-Undang Nomor 2 Tahun 1960 tentang Perjanjian Bagi Hasil Pertanian (Tanah Kering) di Desa Beringin, Kecamatan Bayan, Kabupaten Purworejo. Diponegoro Law Fournal 6(2):1-12.

Sanjaya, M.T.R. (2015). Pengaruh disiplin kerja dan motivasi kerja terhadap kinerja karyawan pada Hotel Ros In, Yogyakarta.

Santosa, M.S.E. (2016). Compromise effect on consumers' behavior. Fournal of Indonesian Economy and Business 31(1): 325-?. https://doi.org/10.22146/jieb.23181

Suharjono, M. (2014). Pembentukan peraturan daerah yang responsif dalam mendukung otonomi daerah. Furnal Ilmu Hukum 10(19):21-37.

https://doi.org/10.30996/dih.v10i19.281

Tompodung, T.C.G., Rushayati, S.B. \& Aidi, M.N. (2018). Efektivitas program adiwiyata terhadap perilaku ramah lingkungan warga sekolah di Kota Depok. Furnal Pengelolaan Sumberdaya Alam Dan Lingkungan 8(2):170-177. https://doi.org/10.29244/jpsl.8.2.170-177

Wee, S. (2013). Development and initial validation of the willingness to compromise scale. Gournal of Career Assessment 21(4):487-501. https://doi.org/10.1177/1069072712475281

Yodi, D. (2020). Efektivitas koordinasi dalam pelaksanaan tugas di Puskesmas Kecamatan Gambir. 2(1):22-41. 